\title{
Review
}

\section{Sistem Penghantaran Obat Transdermal Dissolving Microneedle (DMN) Serta Potensinya Sebagai Penghantaran Vaksin}

\author{
Dissolving Microneedles (DMNs) and Their Potency as Vaccine Delivery \\ Viviane Annisa* \\ ${ }^{1}$ Program Pasca Sarjana, Fakultas Farmasi, Universitas Gadjah Mada, Sekip Utara, Yogyakarta 55281, \\ Indonesia \\ *E-mail: vivianeannisa@mail.ugm.ac.id
}

\begin{abstract}
Abstrak
Keberhasilan vaksinasi tidak hanya tergantung pada efektivitasnya, tetapi juga pada teknologi dalam pembuatan, keamanan, serta kenyamanan pengguna. Penghantaran vaksin konvensional menggunakan jarum hipodermik memiliki keterbatasan yaitu sulitnya proses pembuatan, risiko jarum yang digunakan lebih dari satu kali, serta menimbulkan nyeri. Alternatif penghantaran sediaan vaksin yaitu melalui transdermal. Penghantaran vaksin melalui transdermal memiliki respon proteksi imun yang lebih besar dibandingkan dengan penghantaran melalui injeksi secara subkutan ataupun intramuskular. Dissolving Microneedle (DMN) merupakan sistem penghantaran transdermal yang banyak memiliki keunggulan. DMN telah berhasil menghantarkan sejumlah makromolekul seperti vaksin, insulin, eritropoietin, interferon-a, hormon pertumbuhan, dan heparin. Penggunaan vaksin mandiri dapat menjadi lebih hemat karena mengurangi limbah benda tajam, dan tidak memerlukan penyimpanan suhu rendah. Beberapa penelitian DMN vaksin telah dilakukan uji klinik pada manusia, seperti vaksin influenza.
\end{abstract}

Kata kunci: microneedle, penghantaran transdermal, dissolving microneedle, penghantaran vaksin

\begin{abstract}
The success of vaccination depends do not only on the identification of effective vaccines but also on a technology in making vaccines, safety, and user convenience. Conventional vaccine delivery using hypodermic needles is related to the difficulty of making vaccines, the risk of needles being used more than once, and causing pain. Alternative delivery of vaccine is through transdermal route. Transdermal Delivery of vaccines has a greater immune protection response than delivery through injection either subcutaneously or intramuscularly. Dissolving Microneedle (DMN) is a transdermal delivery system that has many advantagess. DMN has succeeded in delivering a number of macromolecules such as vaccines, insulin, erythropoietin, interferon- $\alpha$, growth hormone, and heparin. Self-administration vaccines can be costeffective because it reduces sharps waste, and does not require low temperature storage. Several DMN vaccine studies have been carried out in human clinical trials, such as influenza vaccines.
\end{abstract}

Keywords: microneedle, transdermal delivery, dissolving microneedle, vaccine delivery system 


\section{PENDAHULUAN}

Keberhasilan vaksinasi tidak hanya tergantung pada efektivitas vaksin, tetapi juga teknologi dalam pembuatan vaksin, keamanan, serta kenyamanan pengguna. Pada penghantaran vaksin konvensional terdapat keterbatasan terkait sulitnya pembuatan vaksin, risiko jarum digunakan lebih dari satu kali, serta menimbulkan rasa sakit (Donnelly dan Singh, 2015). Penghantaran vaksin melalui transdermal merupakan alternatif yang dapat dipilih untuk penghantaran vaksin. Diketahui bahwa penghantaran vaksin melalui transdermal memiliki respon proteksi imun yang lebih besar dibandingkan penghantaran melalui injeksi secara subkutan ataupun intramuskular, sebab kulit tidak hanya sebagai agen fisik, namun juga sebagai barier imunologi yang melindungi tubuh dari eksogen luar (Naito et al., 2012).

Pada umumnya, sediaan obat transdermal berupa krim topikal, plester transdermal, dan jarum hipodermik. Microneedle merupakan teknologi penghantaran obat transdermal menggunakan ratusan jarum berukuran mikrometer (Ita, 2017). Keuntungan microneedle dibandingkan penghantaran transdermal lainnya, yaitu tidak menimbulkan rasa sakit, memiliki onset aksi lebih cepat, permeabilitas dan kemanjuran yang lebih baik, serta memiliki reprodusibilitas hasil dan akurasi yang tinggi terhadap bioavailabilitas (Waghule et al., 2019).

Teknologi Dissolving Microneedles (DMN) telah berhasil menghantarkan sejumlah makromolekul seperti vaksin, insulin, eritropoietin, interferon- $\alpha$, hormon pertumbuhan, dan heparin. DMN tidak menghasilkan residu benda tajam dan tidak berisiko tertinggal patahan dari microneedle karena terlarut dalam tubuh (Naito et al., 2012). Pada ulasan ini, saya akan mendeskripsikan sediaan DMN serta potensinya untuk penghantaran vaksin.

\section{Microneedle Dalam Penghantaran Obat}

Microneedle merupakan teknik secara mekanik berupa jarum ukuran mikrometer yang memilik panjang 100-500 $\mu \mathrm{m}$. Strukturnya berupa piramid atau kerucut, dimana bagian puncak harus tajam agar dapat menembus kulit. Jarum dari sediaan microneedle hanya menembus sampai epidermis sehingga tidak menimbulkan rasa sakit. Microneedle membentuk jalur untuk dilewati oleh obat ke dalam kulit, obat yang dilepaskan kemudian menuju ke dermis lalu ke sirkulasi sistemik. Terdapat empat jenis microneedle, antara lain solid microneedle (membentuk pori pada kulit dan biasanya digunakan sebagai pre-treatment), coated microneedle (obat disalut pada permukaan jarum), dissolving microneedle (terlarut dalam epidermis) dan hollow microneedle (celah jarum diisi dengan larutan obat) (Gambar 1) (Ita, 2017).

Solid microneedle berupa jarum silikon atau logam yang tidak mengandung obat diaplikasikan terlebih dahulu ke dalam kulit lalu kemudian obat dioleskan di permukaan kulit. Jalur yang telah terbentuk oleh jarum mikro akan memudahkan obat untuk masuk melewati stratum korneum sehingga lebih banyak obat yang terabsorpsi ke dalam kulit. Coating Microneedle adalah solid microneedle yang disalut dengan larutan 
penyalut yang mengandung obat. Setelah diaplikasikan ke dalam kulit, obat yang tersalut pada jarum akan terabsorpsi oleh kulit. Hollow Microneedle adalah jarum dengan celah kosong ditengah sebagai tempat untuk obat. Obat akan dilepaskan ketika jarum sudah mencapai ujung dalam epidermis sehingga obat dapat langsung masuk ke dermis. Dissolving Microneedles (DMN) berupa polimer larut air yang dicampur obat kemudian dicetak membentuk jarum ukuran mikro. Ketika masuk ke dalam kulit maka jarum tersebut akan terlarut seluruhnya (Dharadhar et al., 2019; Y. Kim et al., 2012). Difusi obat terjadi oleh adanya kelembapan yang berasal dari cairan interstisial kulit. Microneedle yang penetrasi ke dalam kulit akan membentuk rongga sebagai jalur masuk obat dan jalur keluar cairan interstisial. Difusi obat terjadi oleh adanya kelembapan yang berasal dari cairan interstisial kulit (Lee et al., 2008).

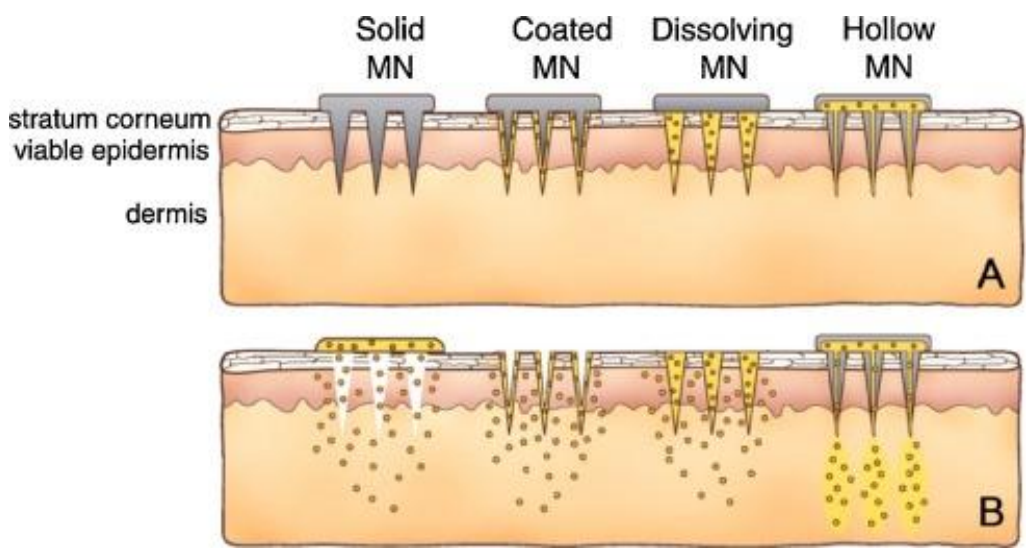

Gambar 1. Jenis Microneedle (MN) dikategorikan menjadi 4, yaitu solid MN, coated $\mathrm{MN}$, dissolving MN, dan hollow MN. Saat sediaan microneedle utuh diaplikasikan ke permukaan kulit $(A)$, obat pada jarum akan dilepaskan masuk ke dalam dermis sehingga yang tersisa dapat berupa jarum atau plester (B) (Ita, 2017)

Faktor penting dalam formulasi DMN adalah keseragaman distribusi jarum serta pemilihan material jarum yang tepat untuk pembuatan DMN. Kriteria material yang dipilih antara lain larut dalam air, kemampuan menembus kulit, kemudahan proses, serta material yang aman seperti polisakarida. Material berupa polisakarida alami memiliki keuntungan, yakni bersifat aman terurai dalam tubuh dan tidak terdeposit, biokompatibel, harga terjangkau, banyak tersedia, dan dapat digunakan tanpa melalui proses dengan kondisi khusus. Contoh polimer yang digunakan untuk formulasi DMN misalnya polivinilpirolidon (PVP), polilaktat (PLA), poli laktat koglikolat (PLGA), dekstran, kondroitin sulfat, asam hyaluronat. Polimer dapat mengontrol pelepasan obat sehingga cocok digunakan untuk terapi pengobatan jangka panjang (Larrañeta et al., 2016; Lee et al., 2008).

DMN lebih menguntungkan dibandingkan dengan jarum silikon dan logam. DMN tidak menghasilkan limbah benda tajam karena polimer yang digunakan dapat terdegradasi di dalam kulit. DMN secara lembut berpenetrasi ke dalam kulit sehingga mencegah kerusakan jaringan akibat tekanan mekanik saat pemberian. DMN juga dapat digunakan secara mandiri tanpa pelatihan medis terlebih dahulu (Waghule et al., 2019). Namun, DMN harus memiliki kekuatan mekanik yang mencukupi untuk 
membuat rongga pada stratum korneum. Hal ini menimbulkan kesulitan untuk mengontrol enkapsulasi dosis dan menghantarkan obat dari DMN selama obat berdifusi dalam air. Kekuatan mekanik jarum dapat ditingkatkan dengan mengurangi aspek rasio geometri sehingga mudah menembus kulit. Pengurangan aspek rasio geometri akan menambah ketajaman jarum sehingga jarum semakin kuat menembus epidermis. DMN memerlukan waktu agar dapat terlarut secara sempurna dan masuk ke dalam kulit (Lee et al., 2008; Waghule et al., 2019).

\section{Pembuatan Sediaan DMN}

Penggunaan material polimer mudah diproduksi menggunakan cetakan ukuran mikro pada suhu kamar (Larrañeta et al., 2016). Pembuatan DMN diawali dengan menyiapkan cetakan kemudian dituang sejumlah formula larutan polimer yang mengandung obat ke dalam cetakan. Gelembung udara dihilangkan dari rongga dengan memberikan tekanan tinggi. Setelah itu larutan residu dihilangkan dari permukaan cetakan lalu dikeringkan. Cairan sebagai alas microneedle dituang lalu diberi tekanan tinggi. Terakhir, tunggu hingga terbentuk padatan sehingga dapat dikeluarkan dari cetakan (Gambar 2) (Chen et al., 2018).

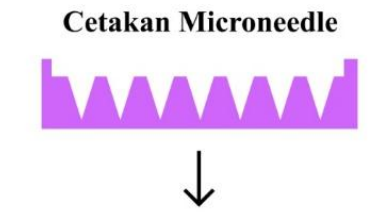

Tambahkan larutan polimer

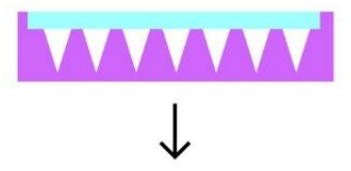

Berikan tekanan tinggi

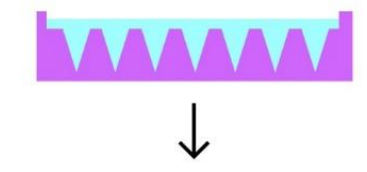

Bersihkan dari residu pelarut Keringkan

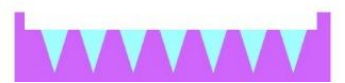

DMN

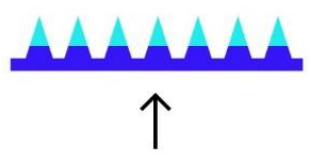

Bekukan dan keluarkan dari cetakan
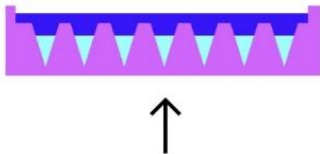

Berikan tekanan tinggi

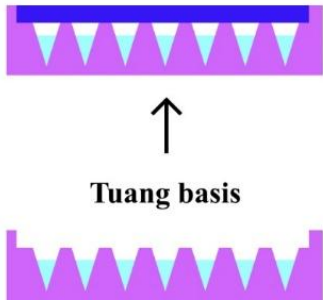

Gambar 2. Proses Pembuatan Dissloving Microneedle (DMN) (Chen et al., 2018)

Pada penelitian Ronnander, et al. (2019) telah dilakukan pembuatan DMN menggunakan basis berupa polimer PVP. Polimer PVP memiliki sifat biokompatibel, larut dalam air, inert serta toksisitas rendah. Bahan tambahan lainnya diperlukan seperti Gliserin dan Polisorbat 80 sebagai surfaktan untuk menurunkan tegangan permukaan sehingga menghasilkan larutan yang seragam pada cetakan microneedle dan membuat microneedle menjadi lebih fleksibel sehingga dapat menembus permukaan yang tidak rata pada kulit. Pembuatan sistem DMN menggunakan cetakan silikon. Saat pembuatan microneedle perlu diperhatikan konsistensi dari bentuk jarum, 
pemerian, dan dimensi tanpa bergantung pada komposisi PVP (Ronnander et al., 2019). Polimer PVP tidak boleh dikombinasikan dengan siklodekstrin karena dapat membentuk kompleks sehingga menurunkan absorpsi air sebesar 36-40\%. Hal ini disebabkan oleh gugus hidroksil pada siklodekstrin dapat membentuk ikatan hidrogen dengan PVP sehingga membatasi pergerakan dari rantai PVP dan dapat meningkatkan kekuatan mekanik dari polimer (Ita, 2017). PVP juga telah digunakan pada penelitian Thakur (2016) untuk penghantaran obat mata karena PVP biokompatibel dengan sel retina sehingga aman digunakan. Obat mata dapat penetrasi ke dalam jaringan okular secara cepat sehingga meningkatkan permeasi obat (Thakur et al., 2016).

\section{DMN Untuk Penghantaran Vaksin}

Penghantaran vaksin melalui transdermal memiliki respon proteksi imun yang lebih besar dibandingkan penghantaran melalui injeksi secara subkutan ataupun intramuskular. Kulit tidak hanya sebagai agen fisik, namun juga sebagai barier imunologi yang melindungi tubuh dari eksogen luar. Di dalam kulit bagian epidermis dan dermis memiliki sel Langerhans dan dendritik untuk melawan patogen yang masuk ke dalam tubuh (Gambar 3). Teknologi microneedle dapat digunakan sebagai alternatif penghantaran vaksin yang biasa menggunakan jarum hipodermal. Jenis microneedle yang sesuai untuk penghantaran vaksin adalah dissolving microneedle (DMN) karena lebih aman dibandingkan dengan jenis microneedle lainnya karena tidak ada risiko tertinggal patahan dari jarum. DMN telah berhasil menghantarkan sejumlah makromolekul seperti vaksin, insulin, eritropoietin, interferon- $\alpha$, hormon pertumbuhan, maupun heparin (Naito et al., 2012; Ono et al., 2017).

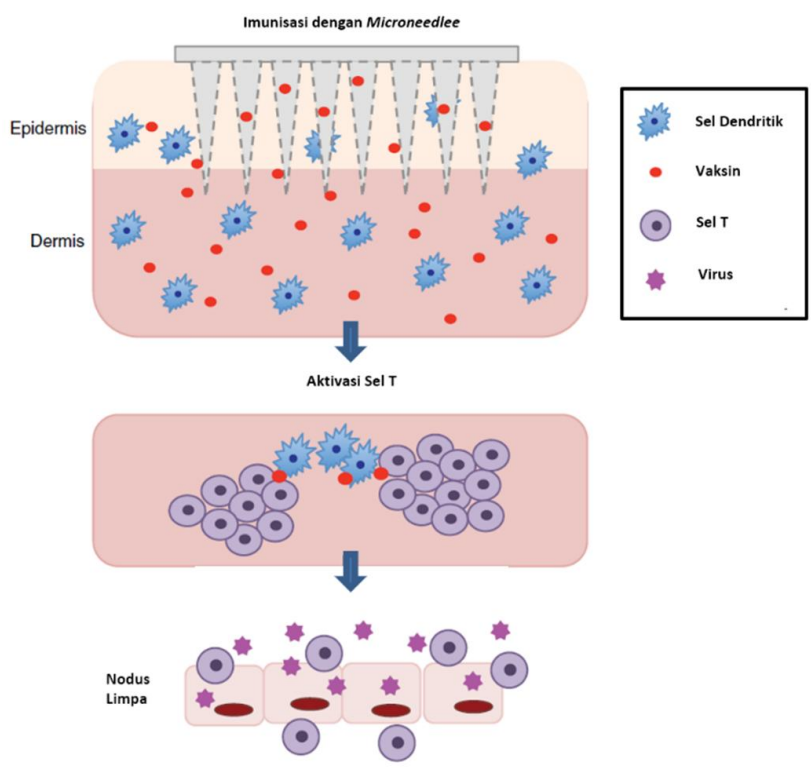

Gambar 3. Mekanisme penghantaran vaksin pada sediaan dissolving microneedle (Donnelly and Singh, 2015)

Kekurangan dari pembuatan DMN vaksin adalah terjadi pemborosan antigen. Hal ini dikarenakan, volume pada rongga cetakan sangat kecil sehingga antigen yang ditambahkan ke dalam cetakan hanya sebanyak $1.8 \%$ 
pada microneedle sedangkan sebanyak $43.3 \%$ ditemukan pada dinding samping cetakan (McCrudden et al., 2015). Untuk mengurangi pemborosan antigen ini, maka dilakukan teknik lokalisasi penambahan antigen pada microneedle untuk mencegah adanya penempelan pada dinding samping cetakan (Rodgers et al., 2018).

Teknik ini dilakukan dengan cara menambahkan larutan antigen ke dalam cetakan terlebih dahulu, setelah itu baru ditambahkan larutan polimer tanpa antigen (blanko). Kemudian dilakukan proses pengeringan, selama proses ini terdapat gradien konsentrasi obat yang menyebabkan terjadinya pencampuran antar lapisan dan terjadi pula evaporasi air dari larutan blanko yang merupakan faktor kunci untuk menentukan drug loading pada jarum (Gambar 4) (Chu et al., 2010). Lokalisasi antigen dapat dicapai dengan menggunakan material basis konsentrasi tinggi untuk mencapai viskositas yang tinggi sehingga menghalangi obat berdifusi masuk ke dalam alas DMN (Rodgers et al., 2018).

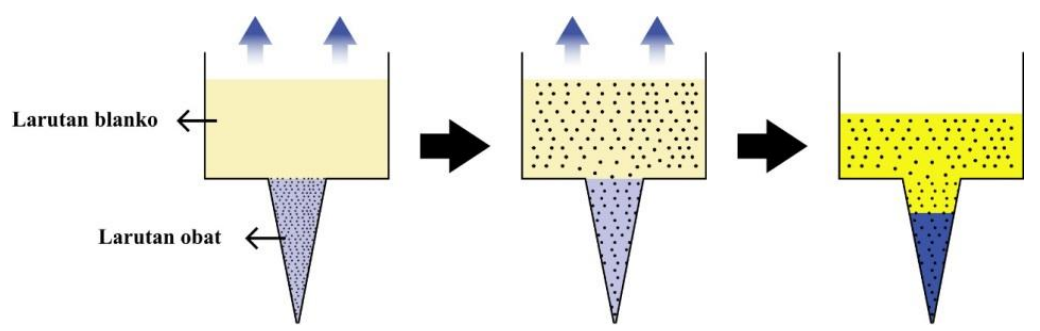

Gambar 4. Proses yang terjadi saat pengeringan, yaitu difusi dan evaporasi (Rodgers et al., 2018)

\section{Pengaplikasian DMN Pada Berbagai Macam Vaksin}

Beberapa penelitian sistem penghantaran vaksin menggunakan DMN telah dilakukan. Pada vaksin hemagglutinin trivalent influenza menggunakan polimer natrium hyaluronat telah diuji klinik pada fase 1 . Respon antibodi yang dihasilkan DMN ekuivalen dengan pemberian secara injeksi subkutan. Penghantaran vaksin influenza secara DMN menghasilkan efektivitas respon IgG yang lebih tinggi dibandingkan dengan injeksi intramuskular. Selain itu, vaksin influenza secara DMN juga dapat terbuat dari material PVP dan CMC (Y. Kim et al., 2012; Leone et al., 2017; Shin et al., 2017).

Efektivitas ovalbumin secara DMN menggunakan basis kondroitin sulfat lebih efisien menginduksi respons antibodi spesifik antigen jika dibandingkan dengan pemberian vaksin secara topikal. Namun, memiliki respon yang sama jika dibandingkan dengan sediaan injeksi hipodermal (Naito et al., 2012). Pada penghantaran vaksin campak, DMN dan vaksinasi subkutan pada dosis yang sama memperlihatkan jumlah respon antibodi yang sama. Penyimpannya pada suhu kurang dari $40^{\circ} \mathrm{C}$ dapat disimpan selama 4 bulan sedangkan sediaan vaksin campak di pasaran hanya sampai 7 dan 90 hari (Edens et al., 2015). Pada penghantaran vaksin untuk Zika virus, DMN memperlihatkan level antibodi yang signifikan lebih tinggi setelah diimunisasi selama 4 minggu (E. Kim et al., 2016). Pada penghantaran vaksin tetanus, dihasilkan level antibodi tetanus-spesifik IgG selama umur tikus 12 minggu dan tetap bertahan hidup saat diberikan toksin tetanus (Siddhapura et al., 2016). Pada antigen rekombinan memiliki 
respon imun yang lebih baik dibandingkan dengan injeksi intramuskular atau intradermal (Wendorf et al., 2011).

Pembuatan DMN vaksin DNA lebih murah dibandingkan dengan tipe vaksin lainnya. Selain itu vaksin DNA lebih aman karena tidak berubah kembali ke bentuk virulen (Kutzler \& Weiner, 2004). Namun, DMN vaksin DNA tidak memperoleh respon imun yang cukup baik pada manusia. Hal ini dapat diatasi dengan pembuatan menggunakan teknik "multi-layer tato". Teknik "multi-layer tato" dengan membuat beberapa layer polielektrolit yang dapat meningkatkan transfeksi lokal dan mengontrol DNA serta adjuvan pada kulit dengan perhitungan kinetik oleh komposisi film. Teknik ini dapat menghasilkan induksi respon imun yang lebih tinggi pada model antigen HIV dibandingkan dengan cara elektroporasi. Memori sel T dan ekspresi gen pada kulit primata lebih tinggi dibandingkan sediaan injeksi intradermal. Hal ini mengindikasikan bahwa sediaan DMN berpotensi untuk meningkatkan vaksin DNA (Demuth et al., 2013; Hong et al., 2013).

Penghantaran berbagai jenis vaksin dalam sediaan plester DMN dapat meningkatkan respon imun atau titer antibodi. Pengaplikasian vaksin dalam sediaan DMN memiliki keuntungan lainnya, yakni dapat mengurangi dosis, terhindar dari risiko infeksi karena DMN berupa sediaan sekali pakai, tidak menghasilkan limbah/sampah medis benda tajam, pengaplikasiannya lebih mudah tanpa bantuan tenaga kesehatan, dapat dilakukan dimana saja tanpa harus datang ke klinik, tidak menimbulkan rasa sakit seperti pada injeksi hipodermal, ukurannya kecil sehingga mudah dibawa, serta biaya produksi massal diperkirakan hampir sama seperti produksi injeksi hipodermal (Koutsonanos et al., 2009).

\section{Arah Masa Depan}

Pada umumnya, teknologi DMN dapat diterapkan dalam pembuatan sediaan vaksin untuk manusia. Beberapa penelitian DMN vaksin telah dilakukan uji klinik pada manusia, seperti vaksin influenza. Permasalahan DMN adalah harus memiliki kekuatan mekanik yang cukup kuat untuk membuat rongga pada stratum korneum. Kekuatan mekanik jarum dapat ditingkatkan dengan mengurangi aspek rasio geometri sehingga mudah menembus kulit. Bentuk geometri jarum berupa kerucut atau piramida, semakin lebar maka dapat menambah volume obat yang terenkapsulasi. Keseragaman distribusi jarum perlu diperhatikan saat pembuatan DMN karena akan mempengaruhi dosis terapi yang dihasilkan (Lee et al., 2008).

Perbedaan kondisi kulit setiap individu menyebabkan dosis yang tercapai ke dalam kulit berbeda. Perbedaan kekuatan dalam pengaplikasian DMN yang berbeda dapat mempengaruhi kedalaman penetrasi (Hong et al., 2013). Maka, perlu alat aplikator yang terjamin konsistensinya antar pengguna agar penghantaran vaksin dapat maksimal. Untuk produksi skala industri, perlu adanya investasi yang besar pada alat dan proses. Meskipun demikian, penggunaan vaksin mandiri dapat menjadi lebih lemat karena mengurangi limbah benda tajam, tidak memerlukan penyimpanan suhu rendah, juga dapat digunakan sendiri tanpa memerlukan bantuan tenaga kesehatan. Polimer yang digunakan harus melalui uji dermatologi untuk mengetahui adanya iritasi, perubahan dalam fungsi barier kulit, serta kemungkinan penetrasi mikroba ke dalam kulit. Satu hal yang penting lainnya adalah perlu dilakukan investigasi terkait biodistribusi dan akumulasi polimer apabila DMN akan diaplikasikan pada manusia (Rodgers et al., 2018). 


\section{REFERENSI}

Chen, J., Huang, W., Huang, Z., Liu, S., Ye, Y., Li, Q., Huang, M., 2018, Fabrication of TipDissolving Microneedles for Transdermal Drug Delivery of Meloxicam, AAPS Pharm Sci Tech, 19(3):1141-1151. https://doi.org/10.1208/s12249-017-0926-7

Chu, L. Y., Choi, S. O., Prausnitz, M. R., 2010, Fabrication of Dissolving Polymer Microneedles for Controlled Drug Encapsulation and Delivery: Bubble and Pedestal Microneedle Designs, Journal of Pharmaceutical Sciences, 99(10):4228-4238. https://doi.org/10.1002/jps

Demuth, P. C., Min, Y., Huang, B., Kramer, J. A., Miller, A. D., Barouch, D. H., Hammond, P. T., Irvine, D. J., 2013, Polymer Multilayer Tattooing for Enhanced DNA Vaccination, Nature Materials, 12(4):367-376. https://doi.org/10.1038/nmat3550

Dharadhar, S., Majumdar, A., Dhoble, S., Patravale, V., 2019, Microneedles for Transdermal Drug Delivery: A Systematic Review, Drug Development and Industrial Pharmacy, 45(2): 188-201. https://doi.org/10.1080/03639045.2018.1539497

Donnelly, R..,dan Singh, T. R., 2015, Novel Delivery Systems for Transdermal and Intradermal Drug Delivery, John WIley and Sons, LLd.

Edens, C., Collins, M. L., Goodson, J. L., Rota, P. A., Prausnitz, M. R., 2015, A Microneedle patch Containing Measles Vaccine is Immunogenic in Non-human Primates, Vaccine, 33(37):4712-4718. https://doi.org/10.1016/j.vaccine.2015.02.074

Hong, X., Wei, L., Wu, F., Wu, Z., Chen, L., Liu, Z., Yuan, W., 2013, Dissolving and Biodegradable Microneedle Technologies for Transdermal Sustained Delivery of Drug and Vaccine, Drug Design, Development and Therapy, 7:945-952. https://doi.org/10.2147/DDDT.S44401

Ita, K., 2017, Dissolving Microneedles for Transdermal Drug Delivery: Advances and challenges, Biomedicine and Pharmacotherapy, 93:1116-1127. https://doi.org/10.1016/j.biopha.2017.07.019

Kim, E., Erdos, G., Huang, S., Kenniston, T., Falo, L. D., Gambotto, A., 2016, Preventative Vaccines for Zika Virus Outbreak: Preliminary Evaluation, EBioMedicine, 13:315-320. https://doi.org/10.1016/j.ebiom.2016.09.028

Kim, Y., Park, J., Prausnitz, M. R., 2012, Microneedles for Drug and Vaccine Delivery, Advanced Drug Delivery Reviews, 64(14):1547-1568. https://doi.org/10.1016/j.addr.2012.04.005

Koutsonanos, D. G., Martin, M. del P., Zarnitsyn, V. G., Sullivan, S. P., Compans, R. W., Prausnitz, M. R., Skountzou, I., 2009, Transdermal Influenza Immunization With Vaccinecoated Microneedle Arrays, PLoS ONE, 4(3). https://doi.org/10.1371/journal.pone.0004773

Kutzler, M. A., dan Weiner, D. B., 2004), Developing DNA Vaccines That Call to Dendritic Cells, Journal of Clinical Investigation, 114(9):1241-1244. https://doi.org/10.1172/JCI23467

Larrañeta, E., Lutton, R. E. M., Woolfson, A. D., Donnelly, R. F., 2016, Microneedle Arrays as Transdermal and Intradermal Drug Delivery Systems: Materials Science, Manufacture and Commercial Development, Materials Science and Engineering R: Reports, 104:1-32. https://doi.org/10.1016/j.mser.2016.03.001

Lee, J. W., Park, J. H., Prausnitz, M. R., 2008, Dissolving Microneedles for Transdermal Drug Delivery. Biomaterials, 29(13):2113-2124. https://doi.org/10.1016/j.biomaterials.2007.12.048

Leone, M., Mönkäre, J., Bouwstra, J. A., Kersten, G., Ma, P., 2017, Dissolving Microneedle Patches for Dermal Vaccination. https://doi.org/10.1007/s11095-017-2223-2

McCrudden, M. T. C., Torrisi, B. M., Al-Zahrani, S., McCrudden, C. M., Zaric, M., Scott, C. J., Kissenpfennig, A., McCarthy, H. O., Donnelly, R. F., 2015, Laser-engineered Dissolving Microneedle Arrays for Protein Delivery: Potential for Enhanced Intradermal Vaccination, Journal of Pharmacy and Pharmacology, 67(3):409-425. https://doi.org/10.1111/jphp.12248

Naito, S., Ito, Y., Kiyohara, T., Kataoka, M., Ochiai, M., Takada, K., 2012, Antigen-loaded Dissolving Microneedle Array as A Novel Tool for Percutaneous Vaccination, Vaccine, 30(6):1191-1197. https://doi.org/10.1016/j.vaccine.2011.11.111

Ono, A., Ito, S., Sakagami, S., Asada, H., Saito, M., Quan, Y. S., Kamiyama, F., Hirobe, S., Okada, N., 2017, Development of Novel Faster-dissolving Microneedle Patches for Transcutaneous Vaccine Delivery, Pharmaceutics, 9(3):1-13. 
https://doi.org/10.3390/pharmaceutics9030027

Rodgers, A. M., Courtenay, A. J., Donnelly, R. F., 2018, Dissolving Microneedles for Intradermal Vaccination: Manufacture, Formulation, and Stakeholder Considerations. Expert Opinion on Drug Delivery, 15(11):1039-1043. https://doi.org/10.1080/17425247.2018.1522301

Ronnander, J. P., Simon, L., Koch, A., 2019, Transdermal Delivery of Sumatriptan Succinate Using Iontophoresis and Dissolving Microneedles, Journal of Pharmaceutical Sciences, 108(11): 3649-3656. https://doi.org/10.1016/j.xphs.2019.07.020

Shin, C. I., Jeong, S. D., Rejinold, N. S., Kim, Y. C., 2017, Microneedles for Vaccine Delivery: Challenges and Future Perspectives. Therapeutic Delivery, 8(6):447-460. https://doi.org/10.4155/tde-2017-0032

Siddhapura, K., Harde, H., \& Jain, S., 2016, Immunostimulatory Effect of Tetanus Toxoid loaded Chitosan Nanoparticles Following Microneedles Assisted Immunization, Nanomedicine: Nanotechnology, Biology, and Medicine, 12(1): 213-222. https://doi.org/10.1016/j.nano.2015.10.009

Thakur, R. R. S., Tekko, I. A., Al-Shammari, F., Ali, A. A., McCarthy, H., Donnelly, R. F., 2016, Rapidly Dissolving Polymeric Microneedles for Minimally Invasive Intraocular Drug Delivery, Drug Delivery and Translational Research, 6(6):800-815. https://doi.org/10.1007/s13346-016-0332-9

Waghule, T., Singhvi, G., Dubey, S. K., Pandey, M. M., Gupta, G., Singh, M., Dua, K., 2019 , Microneedles: A Smart Approach and Increasing Potential for Transdermal Drug Delivery System, Biomedicine and Pharmacotherapy, 109:1249-1258. https://doi.org/10.1016/j.biopha.2018.10.078

Wendorf, J. R., Ghartey-Tagoe, E. B., Williams, S. C., Enioutina, E., Singh, P., Cleary, G. W., 2011, Transdermal Delivery of Macromolecules Using Solid-state Biodegradable Microstructures, Pharmaceutical Research, 28(1): 22-30. https://doi.org/10.1007/s11095010-0174-y

\section{UCAPAN TERIMA KASIH}

Penulis menyampaikan ucapan terima kasih kepada Prof. Dr. Akhmad Kharis Nugroho, M.Si., Apt sebagai dosen pengampun mata kuliah Sistem Penghantaran Obat yang telah memberikan ilmu serta motivasi sehingga penulis dapat membuat artikel ini.

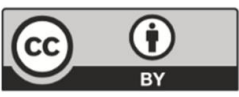

Akses Terbuka Artikel ini dilisensikan di bawah Creative Commons Lisensi Internasional Attribution 4.0, yang memungkinkan penggunaan, berbagi, adaptasi, distribusi, dan reproduksi dalam media atau format apa pun, selama Anda memberikan kredit yang sesuai kepada penulis asli dan sumbernya, memberikan tautan ke lisensi Creative Commons, dan menerangkan jika perubahan telah dilakukan. Gambar atau materi pihak ketiga lainnya dalam artikel ini termasuk dalam lisensi Creative Commons artikel, kecuali dinyatakan sebaliknya dalam batas kredit untuk materi tersebut. Jika materi tidak termasuk dalam lisensi Creative Commons artikel dan penggunaan yang Anda maksudkan tidak diizinkan oleh peraturan perundang-undangan atau melebihi penggunaan yang diizinkan, Anda harus mendapatkan izin langsung dari pemegang hak cipta. Untuk melihat salinan lisensi ini, kunjungi https://creativecommons.org/licenses/by/4.0/deed.id.

(C) The Author(s) 2020 